\title{
Excretion by Benthic Invertebrates \\ as Important Source of Phosphorus \\ in Oligotrophic Ecosystem \\ (Lake Krivoe, Northern Russia)
}

\author{
Nadezhda A. Berezina ${ }^{\text {**, }}$ \\ Alexey A. Maximova, Lyudmila P. Umnova ${ }^{a}$, \\ Xiuyun Caob ${ }^{\text {, Ekaterina S. Arakelova }}{ }^{a}$, \\ Yiyong Zhou ${ }^{\mathrm{b}}$ and Sergey M. Golubkov ${ }^{\mathrm{a}}$ \\ ${ }^{a}$ Zoological Institute RAS \\ 1 Universitetskaya Emb., Saint Petersburg, 199034, Russia \\ ${ }^{b}$ Institute of Hydrobiology, Chinese Academy of Sciences \\ 7 Donghu South Road, Wuhan, Hubei Province, 430072, China
}

We studied contribution of benthic invertebrates to the dissolved phosphates flux from the bottom sediments to the water in an oligotrophic lake (Lake Krivoe, near the White Sea biological station "Kartesh", Northern European Russia) in 2009-2013 with the aim to quantify specific (among and within taxa), spatial (littoral and deep sites) and seasonal variability. The excretion rates $\left(P_{\text {exc }}\right)$ of soluble reactive phosphorus (SRP) were estimated in experiment with dominating taxa of benthic invertebrates (amphipods, oligochaetes, mollusks, and chironomids), freshly collected from the lake. Mass-specific $P$ excretion rate was calculated as $P_{\text {exc }}$ divided by animal dry mass and further used for calculations of benthic $P$ efflux rates. Also, in other experimental series with and without animals (amphipods) we measured extracellular alkaline phosphatase activity. The results showed that the SRP excretion rates varied significantly between taxa and between different-sized individuals within the same taxa (the SRP excretion rate elevates with an increase in individual weight). Notable spatial and seasonal differences in biomass of benthic animals and phosphorus released by them in the lake were found. The calculated phosphorus efflux by excretory activity of benthic animals was more intensive in littoral sites (up to $14.4 \mu \mathrm{mol} \mathrm{m} \mathrm{m}^{-2} \mathrm{~d}^{-1}$ in July), that 7 times greater than maximum efflux in deep areas $\left(2.2 \mu \mathrm{mol} \mathrm{m} \mathrm{m}^{-2} \mathrm{~d}^{-1}\right)$. The mobile burrowing animals (the amphipods Gammarus lacustris, Monoporeia affinis, and Gammaracanthus loricatus) are able to move from the bottom sediments to water and transfer the nutrient; they contributed $80 \%$ of P flux caused by benthic excretion in the lake and affected the activity of the extracellular alkaline phosphatase, increasing its level in water

(C) Siberian Federal University. All rights reserved

* Corresponding author E-mail address: na-berezina@rambler.ru 
3-8 times relative to that in the control (without animals). The high phosphatase activity may increase phosphorus bioavailability by catalyzing hydrolysis of organic phosphorus, and further stimulate primary producers.

Keywords: phosphorus cycle, excretion, zoobenthos, amphipods, phosphatase activity.

Citation: Berezina N.A., Maximov A.A., Umnova L.P., Cao X., Arakelova E.S., Zhou Y., Golubkov S.M. Excretion by benthic invertebrates as important source of phosphorus in oligotrophic ecosystem (Lake Krivoe, Northern Russia). J. Sib. Fed. Univ. Biol., 2017, 10(4), 485-501. DOI: 10.17516/1997-1389-0046.

\title{
Экскреция бентосных беспозвоночных \\ как важный источник фосфора \\ в экосистеме олиготрофного озера
}

\author{
Н.А. Березина ${ }^{a}$, А.А. Максимов ${ }^{a}$, \\ Л.П. Умнова ${ }^{\mathbf{a}}$, С. Цао \\ Е.С. Аракелова ${ }^{a}$ Ю. Жоу ${ }^{\tilde{\sigma}}$ С.М. Голубков ${ }^{\mathrm{a}}$ \\ аЗоологический институт РАН \\ Россия, 199034, Санкт-Петербург, Университетская наб., 1 \\ ${ }^{6}$ Институт гидробиологии Академии наук Китая \\ КНР, 430072, Провиниия Хубей, Ухань, Донгху Саус Роад, 7
}

Работа посвящена количественной оченке вклада бентосных беспозвоночных в поток растворенных фосфатов из донных отложений в воду в олиготрофном озере (оз. Кривое возле Беломорской биологической биостанции «Картеш», север европейской части России) в 2009-2013 г2., которая проводилась с учетом специфических (межвидовых, внутривидовых), пространственных (литораль, профундаль) и сезонных изменений. Удельную по массе тела скорость экскречии фосфатов ( $\mathrm{P}-\mathrm{PO}_{4}{ }^{3-}$, растворенная форма) у доминантных по биомассе бентосных беспозвоночных (амфипод, олигохет, моллюсков и хирономид), собранных в озере, измеряли экспериментально после 4 ч экспозищии в воде с известной начальной концентрацией фосфатов и, совмещая с биомассой таксонов в бентали, использовали для расчета общего потока фосфатов. Кроме того, в других экспериментальных сериях с животными и без животных (амфиподы) измеряли активность внеклеточной щелочной фосфатазы в воде. Результаты показали, что уровни экскреции фосфатов значительно различаются между отдельными таксонами и между индивидуумами разной массы в пределах одних и тех же таксонов (скорость экскреции повышается с увеличением индивидуальной массы животных). Обнаружены большие пространственные и сезонные различия в биомассе бентосных животных и количестве фосфора, выделяемого ими в озере. Вычисленный поток фосфора за счет экскреторной активности бентоса был более интенсивным в литорали, достигая 14.4 нмоль $\mathrm{M}^{-2}$ суm $^{-1}$, что почти в 7 раз превымало максимальный поток в профундали озера 
(2.2 цмоль м $\left.^{-2} \mathrm{cym}^{-1}\right)$. Aмфиподы Gammarus lacustris, Monoporeia affinis u Gammaracanthus loricatus, способные активно перемещаться в толще донных отложений и плавать в воде, переносили путем экскреции до 80 \% от общего потока фосфатов и влияли на активность внеклеточной щелочной фосфатазы, увеличивая ее активность в 3-8 раз по сравнению c контролем (без животных). Высокая активность фосфатазы может увеличить биодоступность фосфора, катализируя гидролиз его органических форм, что, в свою очередь, стимулирует рост первичных продуцентов.

Ключевые слова: фосфор, экскреция, зообентос, амфиподы, активность фосфатазы.

\section{Introduction}

Being a key element in DNA and a variety of other biomolecules, phosphorus (P) is a vital element for all living organisms (Westheimer, 1987) and is the limiting element for photosynthetic primary production in freshwater ecosystems (Schindler, 1977; Hecky, Kilham, 1988). Lake sediments are known to be a long-term sink for $\mathrm{P}$, and its capacity to retain $\mathrm{P}$ affects ecosystem productivity to a large degree. The level of sediment oxygen is important for the burial and recycling of dissolved phosphates, and in oxic sediments, usually relatively $\mathrm{P}$ rich, low or even negative fluxes (i.e., uptake of dissolved inorganic phosphorus (DIP) with pore water) are often estimated, indicating efficient trapping mechanisms of DIP (Ingall et al., 1993).

Internal $\mathrm{P}$ sources such as $\mathrm{P}$-flux via sediment-water interface by physical, chemical, and biological mechanisms may play important role for producers in lakes with low external load (from catchment areas). At present, the conceptual theory of role of aquatic animals in internal $\mathrm{P}$ load in lakes left a lot of unsolved questions, including relationships between efficiency of food assimilation and $P$ regeneration. Non-assimilated phosphorus may be excreted at various proportions, and assimilated phosphorus is also may variably be released with metabolites. Phosphorus used for the somatic growth (containing in benthic biomass) may later be included in the $\mathrm{P}$ cycling through food web interactions.

It was shown that benthic animals can release dissolved phosphates from oxic sediment through their excretory activity (Ji et al., 2011). They can excrete $\mathrm{P}$ directly by egestion, releasing particulate phosphorus with feces and dissolved phosphorus with urine. P release rate was found to be a function of the mass of animals' body (Schindler, Eby, 1997; Golubkov, Berezina, 2012) and $P$ content in their food (Vanni, 2002; Griffiths, 2006). Also, P content in the body of aquatic animals correlates positively with $\mathrm{P}$ excretion rate (Torress, Vanni, 2006).

Differences in the $\mathrm{P}$ excretion rate between diverse benthic taxa determine their function in ecosystem and might be important for understanding of their role in nutrient cycling. For example, the mobile benthic amphipod Gammarus lacustris Sars, 1863 released notably more P (Wilhelm et al., 1999) than infaunal burrowing chironomids (Tarvainen et al., 2005).

In addition, quantification of the role of benthic macrofauna as suppliers of dissolved phosphates and their bioavailability for algae and bacteria is necessary. It is considered that aquatic animals release dissolved phosphorus in the form of soluble reactive orthophosphates (SRP), which is almost completely available for algae (Vanni et al., 2001). On the other hand, some studies found that dissolved $\mathrm{P}$ fraction was excreted in 
organic form by some amphipods and tubificids (Johannes, 1964; Gardner et al., 1981). In this case, direct relationships between $\mathrm{P}$ excreted by animals and enzymatic activity of bacteria and algae could be expected.

It is known that bacteria and microalgae produce extracellular phosphatases to hydrolyze organic phosphorus for compensation of ambient available phosphorus deficiency in lake system (Cao et al., 2005). Also, it had been shown that some aquatic animals can affect the activity of the extracellular enzymes of bacteria or algae (Vrba, Machacek, 1994; Luo, Gu, 2016). For example, burrowing mangrove crab impacted the sediment nutrient cycling, thereby accordingly changing enzymatic activity (including acid phosphatase) and number of bacteria (Luo, Gu, 2016).

By present, there is some data on spatial and seasonal variability of dissolved phosphorus release by zoobenthic taxa in eutrophic ecosystems (Devine, Vanni, 2002; Ji et al., 2011, 2015), but there is no any quantitative data on benthic animal's contribution to internal $\mathrm{P}$ flux in oligotrophic lakes. Low-populated northern region of Russia is rich in clear-water lakes (more than 60000 lakes) that are characterized by scarce external load and low production. This paper focuses on study of biological mechanisms of dissolved phosphate release in sedimentwater interface in oligotrophic lake. The study was performed in high-latitude freshwater lake, situated in the northern Karelia on White Sea coast (Lake Krivoe). Main purposes include: study of differences in $\mathrm{P}$ excreted among and within taxa; evaluation of their contribution to the P flux; quantification of spatial and seasonal variability of benthic biomass and excreted phosphorus in the lake. Furthermore, we verified experimentally idea that excretory activity of benthic animals can influence the extracellular phosphatase activity and, therefore, stimulate growth of producers.

\section{Material and methods}

Study lake

Lake Krivoe $\left(66^{\circ} 21^{\prime} \mathrm{N}, 33^{\circ} 38^{\prime} \mathrm{E}\right)$ is subarctic oligotrophic small lake, located on the shore of Chupa Bay, White Sea near Cape Kartesh, Northern Russia (Fig. 1). This lake is the most typical lake on the Baltic crystal platform (Table 1). Littoral (depth $<3 \mathrm{~m}$ ) contributed $20 \%$ to the total lake area $\left(0.5 \mathrm{~km}^{2}\right)$. Sediments consisted of finely divided grey silt, clays, mineral and organic matter in central sites, while sand, stones, and relatively coarse materials (leaves, detritus) are typical in littoral zone.

\section{Sampling}

Samples of macrozoobenthos were collected from four sites, two deep water (sites 1 and 2) and two shallow-water littoral (sites 3 and 4, Fig. 1) during the season (May-October) of 2009-2013 in order to study the benthic taxonomical composition, abundance, biomass and dominating taxa $(>10 \%$ of the total biomass). Samples were taken with Van Veen grab $\left(0.025 \mathrm{~m}^{2}\right)$ at deep sites and by MordukhaiBoltovskoj core sampler $\left(0.005 \mathrm{~m}^{2}\right)$ at littoral sites in five and six replicates, respectively. The samples were sieved through a $0.25 \mathrm{~mm}$ mesh, rinsed with the clean water, preserved with $10 \%$ formaldehyde and stored in plastic zip-bags before laboratory analysis.

The abundance and biomass of the megabenthic (body length up to $40 \mathrm{~mm}$ ) mobile amphipod Gammaracanthus loricatus (Sabine 1824) (subsp. aestuariorum), common at depths of 24-32 m, was determined by trapping and the Petersen's marking method (Ricker, 1975). This species inhabits the deepest part (10\%) of the lake, where traps were hanged. Two hundred marked individuals (M) were released into the lake in the $6 \times 6 \mathrm{~m}^{2}$ area within location of this species (St 1). Marks were made by light mutilating on third left coxal plate of each amphipod. Four days after this 


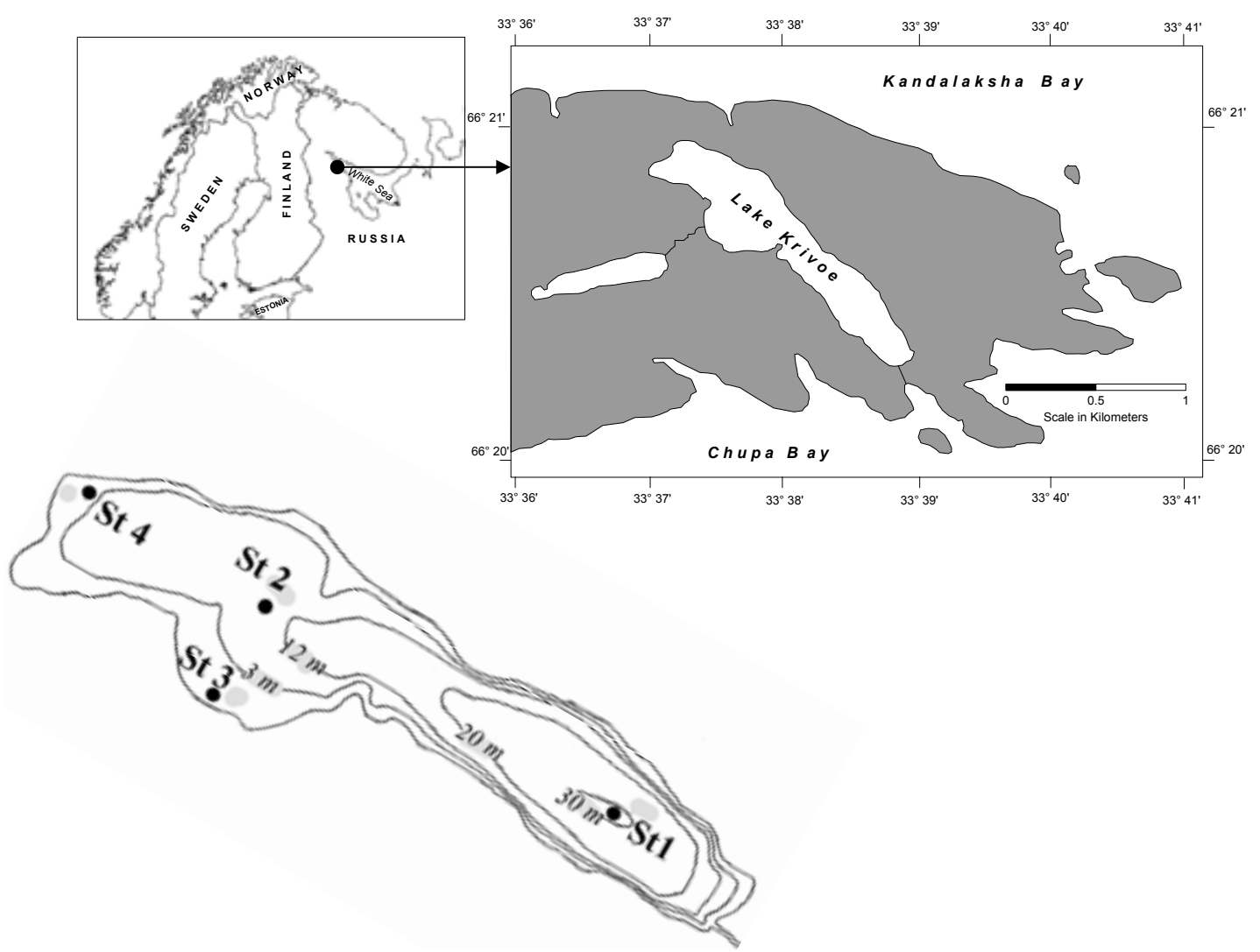

Fig. 1. Location of Lake Krivoe (Kandalaksha Bay coast, White Sea) and bathymetric map showing sampling sites (St. 1-4)

Table 1. Main physical and chemical variables of Lake Krivoe during period of study

\begin{tabular}{|l|c|}
\hline \multicolumn{1}{|c|}{ Parameters } & Variables \\
\hline Surface area, $\mathrm{km}^{2}$ & 0.5 \\
Mean (max) depth, $\mathrm{m}$ & $12(32)$ \\
Transparency, m & $4.5-6.8$ \\
Water color, Pt-Co & 30 \\
Mineralization, $\mathrm{mg} \mathrm{L}^{-1}$ & $45-50$ \\
Surface (bottom) Oxygen, $\mathrm{mg} \mathrm{O}_{2} \mathrm{~L}^{-1}$ & $8.6-12.1(4.9-11.4)$ \\
Surface (bottom) $\mathrm{pH}$ & $7.4-7.7(6.8-7.3)$ \\
Total phosphorus (TP), $\mathrm{mg} \mathrm{m}^{-3}$ & $8-84$ \\
Particulate phosphorus (PP), $\mathrm{mg} \mathrm{m}^{-3}$ & $1.7-6.7$ \\
Chl a, mg m-3 & $0.2-3.0$ \\
Primary production rate, $\mathrm{mg} \mathrm{C} \mathrm{m}^{-2} \mathrm{~d}^{-1}$ & \\
Phytoplankton & $85-580$ \\
Macrophytes & 500 \\
\hline
\end{tabular}


release, over-night trapping was performed. The G. loricatus population size (N) was estimated taking into account total number of marked (M) and caught $(\mathrm{C})$ animals, and number of marked animals caught in the trap ( $\mathrm{R}$, recaptured marks): $\mathrm{N}=\mathrm{MC} / \mathrm{R}$.

In laboratory all animals were picked out the benthic samples under stereoscopic microscope (MBS-10) and sorted into eight taxonomic groups: Oligochaeta, Hirudinea, Gastropoda, Bivalvia, Amphipoda, Chironomidae, aquatic insects and others. The animals were counted and weighed on an electronic balance to the nearest $0.01 \mathrm{mg}$. Before weighting water was removed from animal body with filter paper (wet weight, the mollusk shells are included). To get dry weight, material was dried in thermostat at $\mathrm{T}=50-60{ }^{\circ} \mathrm{C}$ for $96 \mathrm{~h}$ to constant weight.

\section{Experiments}

Animals of seven dominating taxa were collected at study sites to measure dissolved phosphate excretion rate in laboratory experiments: amphipods (Gammarus lacustris, Monoporeia affinis (Lindström, 1855), and Gammaracanthus loricatus (subsp. aestuariorum)), mollusks Lymnaea stagnalis (Linnaeus, 1758) and Sphaerium suecicum ${ }^{1}$ (Clessin in Westerlund 1871), oligochaete Lumbriculus variegatus (Müller, 1774), and larvae of the chironomids Sergentia coracina (Zetterstedt, 1850). Larvae of aquatic insects (Ephemeroptera, Trichoptera, Plecoptera, Odonata and other insects) are regarded as temporary inhabitants in the lake; high number of species occurred in May-June at generally low biomass $(<5 \%)$ distributed irregularly. Therefore, they were not used in measurements within the frame of this study.

Some authors consider that Sphaerium suecicum is a synonym of S. corneum Linnaeus 1758 (Vinarski, Kantor, 2016). The taxonomy of genus Sphaerium needs further clarification, so individuals from Lake Krivoe, used in our experiments, were identified as $S$. suecicum.
The $\mathrm{P}_{\text {exc }}$ by some aquatic insects and other species from the lake were provided in (Golubkov, Berezina, 2012).

The excretion rates of dissolved orthophosphates $\mathrm{P}_{-} \mathrm{PO}_{4}{ }^{3-}$ (soluble reactive phosphorus, SRP) were estimated by the method described earlier (Devine, Vanni, 2002; Ji et al., 2011). The $P$ excretion rate was measured in each taxon separately, using from 1 to 20 individuals of each species and increasing the number from larger to smaller individuals. The animals were put in 50-120 $\mathrm{ml}$ bottles filled with filtered (through a $0.45 \mu \mathrm{m}$ pore size membrane filter) lake water and were incubated in the dark during four hours at temperatures $20{ }^{\circ} \mathrm{C}$ and $10{ }^{\circ} \mathrm{C}$. The control (bottles without animals) was incubated at the same conditions to find changes in the nutrient due to other reasons than animals' activity.

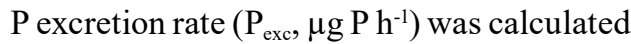
as a difference between SRP concentrations in treatment and control divided by experiment duration (4 h). Obtained empirical data on $\mathrm{P}_{\mathrm{exc}}$ were presented as a power function of individual wet body mass. $\mathrm{P}_{\text {exc }}$ divided by dry weight (DW, $\mathrm{mg}$ ) of animals or the mass-specific $\mathrm{P}$ excretion rate $\left(\mathrm{P}_{\text {exc }} / \mathrm{DW}, \eta \mathrm{mol} \mathrm{mg} \mathrm{m}^{-1} \mathrm{~h}^{-1}\right)$ was further used for calculations of benthic $\mathrm{P}$ efflux rate. Total $\mathrm{P}$ efflux rate $\left(\mu \mathrm{mol} \mathrm{P} \mathrm{m} \mathrm{m}^{-2} \mathrm{~d}^{-1}\right)$ was calculated as a sum of SRP released by each taxon for $24 \mathrm{~h}$ multiplied by its biomass in the lake.

The value of the temperature coefficient $\left(\mathrm{Q}_{10}\right)$ was calculated for each species by the formula: $\mathrm{Q}_{10}=\left(\mathrm{R}_{2} / \mathrm{R}_{1}\right)^{10 /(\mathrm{T} 2-\mathrm{T} 1)}$, where $\mathrm{R}_{\mathrm{n}}$ is the $\mathrm{SRP}$ excretion rate at the temperature $\mathrm{T}_{\mathrm{n}}\left({ }^{\circ} \mathrm{C}\right)$, using the rates measured at $\mathrm{T} 10^{\circ} \mathrm{C}$ and $20^{\circ} \mathrm{C}$. It characterizes the rate of an increase in $\mathrm{P}_{\mathrm{exc}}$ for every 10-degree rise in water temperature. Particularly, it shows $\mathrm{P}_{\text {exc }}$ differences between warm and cold periods. This coefficient was used at calculations of $\mathrm{P}$ efflux at different water temperature (seasonal changes). 
To measure the alkaline phosphatase activity (APA) we performed $4 \mathrm{~h}$ exposition of bottles filled with lake water without and with fieldcollected 3-15 ind. of the amphipod G. lacustris. The experiments were performed as described above but at light and $20^{\circ} \mathrm{C}$.

APA and SRP in water and weight of animals were measured immediately after experiment.

\section{Phosphorus and phosphatase}

activity measurements

Phosphorus that reacted with ammonium molybdate was considered to be soluble reactive inorganic phosphorus (SRP). SRP in water was estimated using a standard method with photocolorimetry (Murphy, Riley, 1962). The total phosphorus (TP) was determined by the method established by Golterman et al. (1978).

Bulk extracellular alkaline phosphatase activity (APA, $\mu \mathrm{mol} \mathrm{l}^{-1} \mathrm{~h}^{-1}$ ) in the water samples was determined using a procedure modified from Gage and Gorham (1985) and Boon (1989). APA was determined in unfiltered samples. Triplicate $5 \mathrm{~mL}$ water samples were supplied with Tris$\mathrm{HCl}$ buffer ( $\mathrm{pH}$ 8.5; final concentration $13 \mathrm{mmol}$ $\mathrm{L}^{-1}$ ), $\mathrm{Na}_{3} \mathrm{~N}$ (final concentration $5 \mathrm{mmol} \mathrm{L}^{-1}$ ), and p-nitrophenyl phosphate (final concentration $0.3 \mathrm{mmol} \mathrm{L}^{-1}$ ), and incubated at $37{ }^{\circ} \mathrm{C}$ for $4 \mathrm{~h}$. Absorbency of p-nitrophenol was measured spectrophotometrically at $410 \mathrm{~nm}$ in a $1-\mathrm{cm}$ cuvette. Sterilized distilled water was taken as a blank sample.

\section{Statistics}

All measured parameters were expressed as mean \pm SE (standard error). Nonparametric Spearman Rank Correlation coefficient served to test relationships between SRP, APA and abundance and biomass of animals. Differences in variables between sites, months were estimated by analysis of variance (ANOVA). The t-test was used to determine if two sets of data were significantly different from each other. Prior to the analysis, data were tested for homogeneity and $\operatorname{Lg}(\mathrm{x}+1)$-transformation was used in the case of heterogeneous variances. Pair-wise comparison of slope and intercept of regression lines was performed.

\section{Results}

Lake characteristics

Table 1 summarizes the basic physical and chemical characteristics of the lake. From first studies of this lake in 1960s (Winberg, 1975) it remains oligotrophic ecosystem with low nutrients and primary production of phytoplankton as well as macrophytes due to general hydrological features of lakes in northern region and low anthropogenic impact on its ecosystem. Lake situates in unpopulated region of Russia and only seasonal biological station (with 200 people's annual attendance) acts nearby its shore since 1957. The ice-free period at the Lake lasts from late May-June to October, approximately 140 days; from November to late May it is icecovered. The surface water temperature reaches $4-5{ }^{\circ} \mathrm{C}$ in May-early June, $10-16{ }^{\circ} \mathrm{C}$ in June and August-September, and maximum in July (about $20{ }^{\circ} \mathrm{C}$ ). As a rule, from June to September, a thermocline is recorded at depths of 5-7 $\mathrm{m}$ with $>10{ }^{\circ} \mathrm{C}$ in the epilimnion and $4-7{ }^{\circ} \mathrm{C}$ in deeper water. The bottom waters at deepest part $(30 \mathrm{~m})$ keep constantly $4-5{ }^{\circ} \mathrm{C}$ and $60-90 \%$ of oxygen.

Total phosphorus (TP) concentration varied from 8 to $84 \mathrm{mg} \mathrm{m}^{-3}$, with maximum in surface waters under ice in April or at the beginning of May (Fig. 2). Also, lake ice (50-60 $\mathrm{cm}$ thick) contained $54-76 \mathrm{mg} \mathrm{m}^{-3}$ of TP. Particulate phosphorus contributed from 4 to $42 \%$ to the water TP tending to some elevation in hypolimnion. Dissolved orthophosphates ranged $0.1-12.5 \mathrm{mg} \mathrm{m}^{-3}$ in June and increased (29-44 $\left.\mathrm{mg} \mathrm{m}^{-3}\right)$ in August, with a maximum in the bottom water (Table 2). 


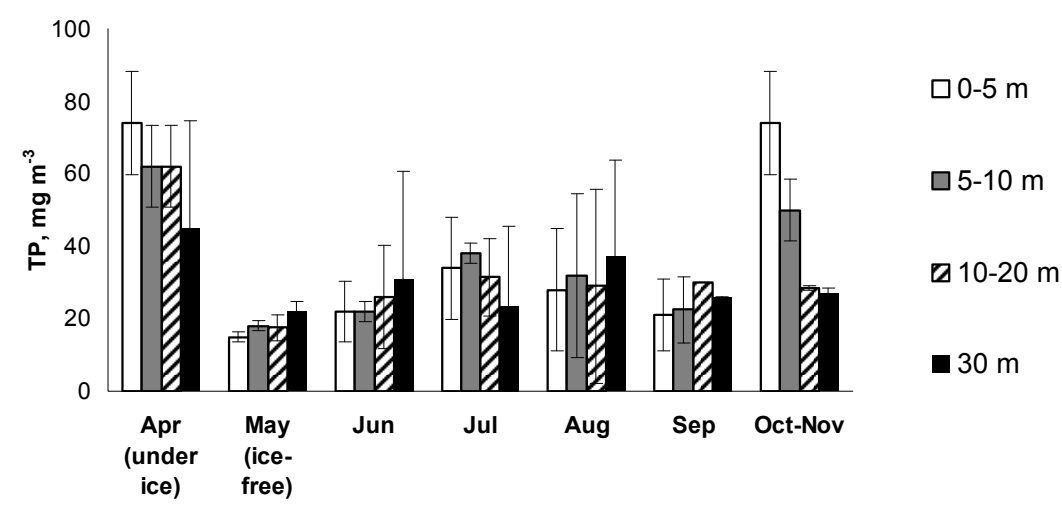

Fig. 2. Seasonal dynamics of the total phosphorus (TP, $\mathrm{mg} \mathrm{m}^{-3}$ ) in water column of Lake Krivoe (means \pm standard deviations for 2009-2013)

Table 2. Dissolved orthophosphates $\left(\mathrm{PO}_{4}^{3-}, \mathrm{mg} \mathrm{m}^{-3}\right)$ at various depths of Lake Krivoe during summer months $\left(\mathrm{PO}_{4}{ }^{3-}\right.$ is equivalent to SRP)

\begin{tabular}{|c|c|c|}
\hline Depth (m) & Month & $\mathrm{PO}_{4}^{3-}, \mathrm{mg} \mathrm{m}^{-3}$ \\
\hline \multirow{3}{*}{ Surface (0-5) } & June & $0.1-10.0$ \\
& July & $11.6-12.5$ \\
& August & 29.3 \\
\hline $5-10$ & June & $2.6-10.0$ \\
& July & 12.0 \\
& August & $29.0-32.0$ \\
\hline \multirow{2}{*}{$10-20$} & June & $5.1-12.5$ \\
& July & 14.4 \\
& August & $31.0-35.0$ \\
\hline Bottom (30) & June & 10.0 \\
& July & 20.0 \\
& August & 43.6 \\
\hline
\end{tabular}

\section{Abundance and biomass}

\section{of zoobenthos in lake}

The total biomass of macrozoobenthos varied between 0.2 and $23 \mathrm{~g} \mathrm{~m}^{-2}$ (wet weight) achieving maximum in littoral sites (Fig. 3). Six dominating species were distinguished: the amphipods $G$. lacustris and $M$. affinis, the oligochaete $L$. variegatus, the chironomid $S$. coracina, the gastropod L. stagnalis, and the bivalve $S$. suecicum. Maximum biomass $22 \mathrm{~g} \cdot \mathrm{m}^{-2}$ at St 3 was recorded in March 2011 and $23 \mathrm{~g} \cdot \mathrm{m}^{-2}$ at
St 4 in May-June 2010 (Fig. 3), mainly on account of high development of the amphipod G. lacustris and the bivalve S. suecicum.

The megabenthic amphipod G. loricatus (body length $22-40 \mathrm{~mm}$ and body wet weight $0.187-0.878 \mathrm{~g}$ ) was common at St 1 . Estimated by Petersen's marking method, its abundance and biomass varied in July-September in the ranges of 10-30 ind. $\mathrm{m}^{-2}$ and 5-25 $\mathrm{g} \mathrm{m}^{-2}$, respectively.

Significant differences in the total biomass were found between littoral and deep sites in 

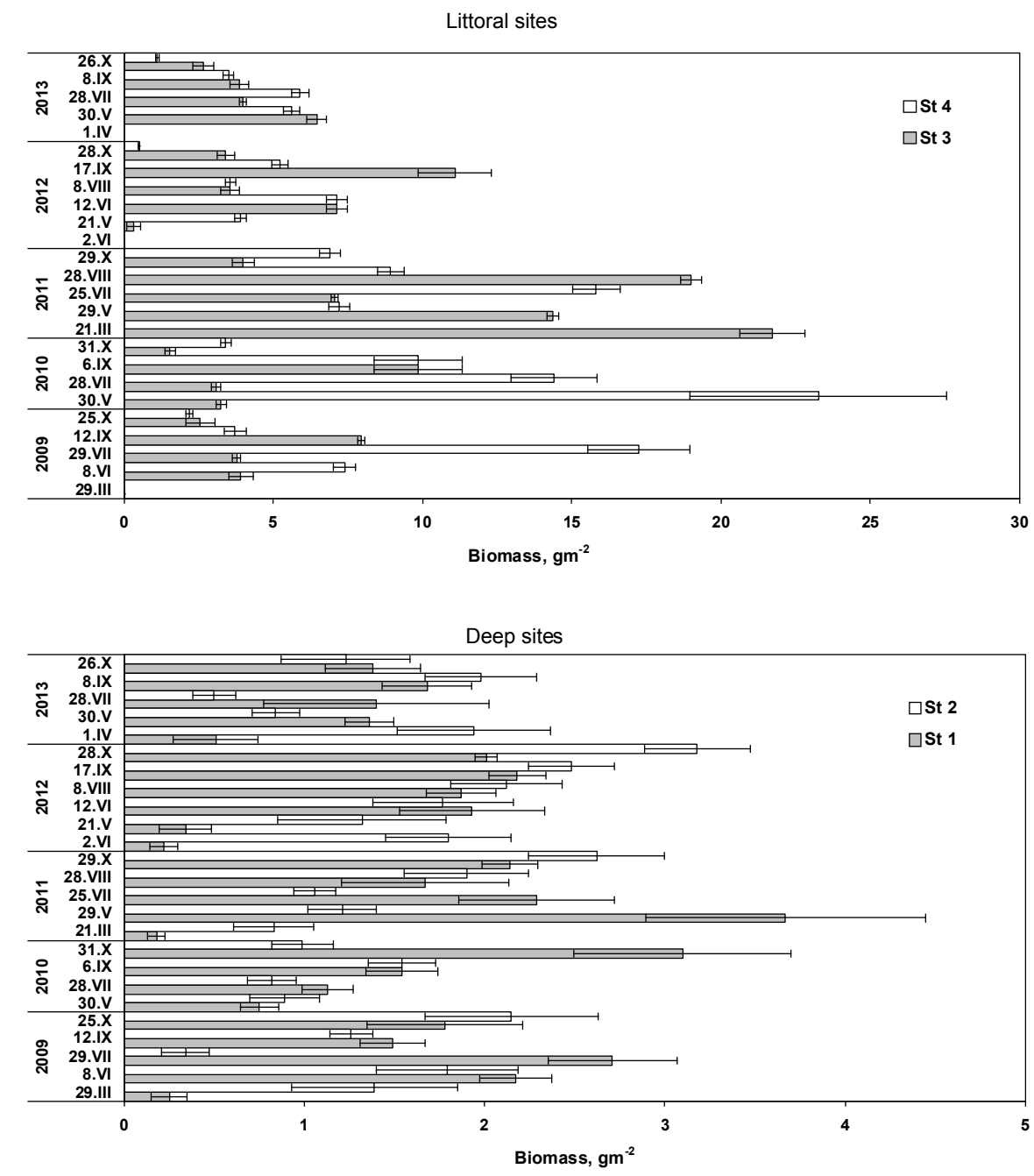

Fig. 3. Seasonal dynamics of the total wet biomass of zoobenthos (mean \pm standard error) at four study sites of Lake Krivoe in 2009-2013

Table 3. Average seasonal (March-October) biomass $\left(\mathrm{g} \mathrm{m}^{-2}\right)$ and P-efflux $\left(\mu \mathrm{mol} \mathrm{m} \mathrm{m}^{-2} \mathrm{~d}^{-1} \pm \mathrm{SE}\right.$ for whole period of observation (2009-2013) of macrozoobenthos at various sites of Lake Krivoe

\begin{tabular}{|c|c|c|c|c|}
\hline Variable & St 1 & St 2 & St 3 & St 4 \\
\hline Biomass & $1.59 \pm 0.24$ & $1.50 \pm 0.18$ & $6.58 \pm 1.22$ & $8.08 \pm 1.21$ \\
\hline P-efflux & $1.26 \pm 0.20$ & $1.41 \pm 0.23$ & $6.50 \pm 1.11$ & $7.62 \pm 1.75$ \\
\hline
\end{tabular}

the lake (ANOVA, $\mathrm{F}=13.5 ; \mathrm{p}<0.001$ ). The mean total biomasses for five studied years were similar between deep sites: St 1 and St 2 (Table 3). Biomass in littoral was significantly (t-test, $\mathrm{p}<0.001)$ 4-fold higher than in deep sites. At the same time, the differences in mean biomasses between St 3 and St 4 were insignificant $\left(t_{3,4}=0.15 ; p>0.05\right)$. 
At all study sites we found significant differences in biomass and abundance between taxa (ANOVA, $\mathrm{p}<0.001$ ). G. lacustris with biomass of $0.8-5.5 \mathrm{~g} \cdot \mathrm{m}^{-2}$ accounted for $22-56 \%$ of the total benthic biomass and bivalve mollusk $S$. suecicum $\left(0.4-3.8 \mathrm{~g} \cdot \mathrm{m}^{-2}\right)$ comprised 14-37 \%. Also, L. variegatus contributed notably $\left(0.1-0.9 \mathrm{~g} \cdot \mathrm{m}^{-2}, 8-23 \%\right)$. Biomass of littoral chironomid larvae was $<5 \%$ of total in summer and increased to 15-32\% (up to $2.5 \mathrm{~g} \cdot \mathrm{m}^{-2}$ ) in the late AugustOctober (Fig. 4). Aquatic insects (Trichoptera, Plecoptera, Megaloptera, and Ephemeroptera) were abundant in April-May $\left(3.27 \mathrm{~g} \cdot \mathrm{m}^{-2}, 33 \%\right)$, and then decreased in their biomass abruptly (after May-June flight out of lake), varying $0.1-0.8 \mathrm{~g} \cdot \mathrm{m}^{-2}$. At deep sites $80 \%$ of the total biomass was on account of the chironomid $S$. coracina (St 1) and the amphipod M. affinis (St 2). Seasonal differences in the biomass and abundance of taxa were insignificant at St 1 (ANOVA, $F=0.93-1.69 ; \mathrm{p}>0.05$ ) and St $2(\mathrm{~F}=1.31-1.62 ; \mathrm{p}>0.05)$, while they were significant at St 3 and St 4 (biomass: $\mathrm{F}=2.41-3.06 ; \mathrm{p}=0.001-0.002$; abundance: $\mathrm{F}=2.89-6.09 ; \mathrm{p}<0.001)$.

\section{Excretion rate}

Direct positive relationships were observed between the individual excretion rates $\left(\mathrm{P}_{\text {exc }}\right)$ and the individual weight of animals. For example,

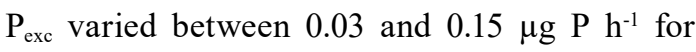
G. lacustris with 45-128 mg of body wet weight (WW) and $0.1-40.35 \mu \mathrm{g} \mathrm{P} \mathrm{h}{ }^{-1}$ for $150-420 \mathrm{mg}$ $G$. loricatus. The correlation coefficient between $\mathrm{P}_{\mathrm{exc}}$ and body weight of $S$. coracina was low (0.26) and insignificant. For other taxa $\mathrm{P}_{\text {exc }}-\mathrm{WW}$ correlations were highly significant. $\mathrm{P}_{\text {exc }}-\mathrm{WW}$ relationships were approximated by a power function (Fig. 5): 1) S. suecicum $\left.\mathrm{P}_{\mathrm{exc}}=0.03 \mathrm{WW}^{0.81}, \mathrm{n}=12, \mathrm{R}^{2}=0.63 ; 2\right)$ L. stagnalis $\mathrm{P}_{\mathrm{exc}}=0.0003 \mathrm{WW}{ }^{1.32}, \mathrm{n}=8, \mathrm{R}^{2}=0.94$; 3) G. lacustris $\mathrm{P}_{\mathrm{exc}}=0.196 \mathrm{WW}^{0.66}, \mathrm{n}=34, \mathrm{R}^{2}=0.34$; 4) G. loricatus $\mathrm{P}_{\mathrm{exc}}=0.073 \mathrm{WW}^{0.82}, \mathrm{n}=40$, $\left.\mathrm{R}^{2}=0.89 ; 5\right)$ M. affinis $\mathrm{P}_{\text {exc }}=0.086 \mathrm{WW}^{0.74}, \mathrm{n}=18$, $\mathrm{R}^{2}=0.81$; 6) L. variegatus $\mathrm{P}_{\mathrm{exc}}=0.041 \mathrm{WW}^{0.88}$, $\mathrm{n}=16, \mathrm{R}^{2}=0.73$; 7) S. coracina $\mathrm{P}_{\mathrm{exc}}=0.05 \mathrm{WW}^{0.88}$, $\mathrm{n}=35, \mathrm{R}^{2}=0.16$.

Regression lines for SRP excreted by $G$. lacustris, G. loricatus, and $L$. variegatus differ significantly according to F-test $(\mathrm{p}<0.001)$. Also, F-test revealed significant differences $(p<0.001)$ in dispersions between
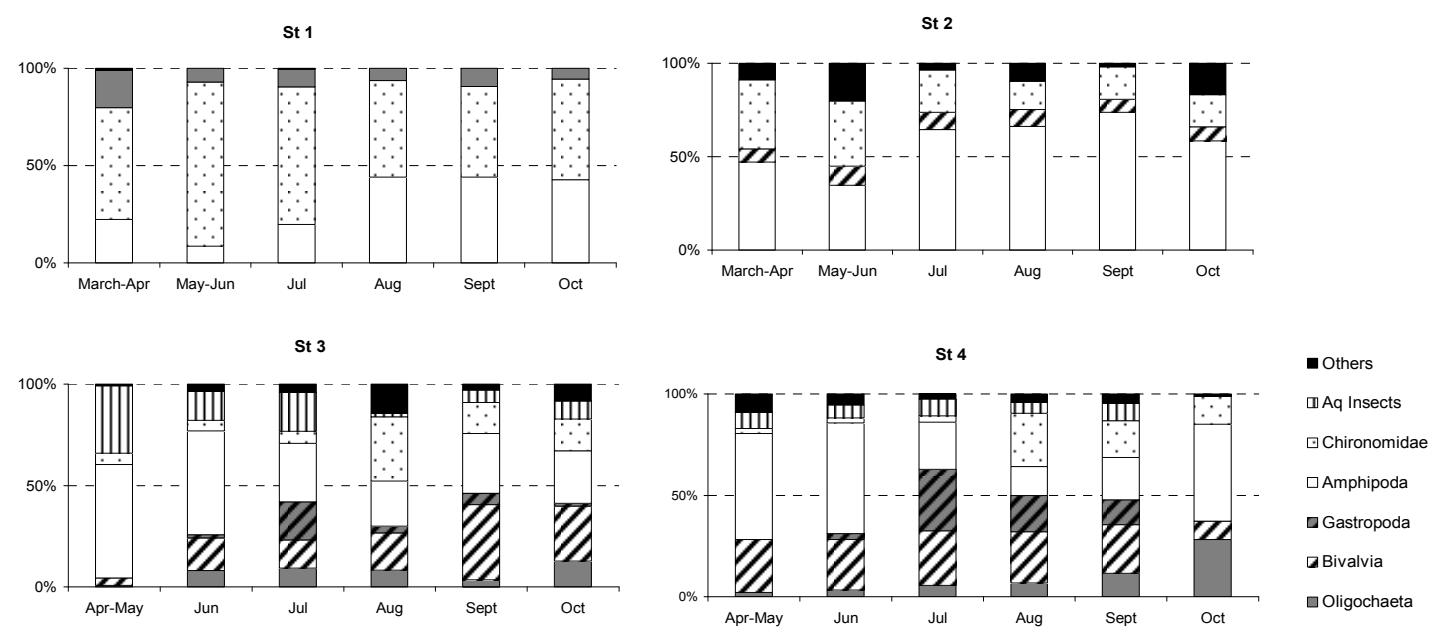

Fig. 4. Contribution (\%) of various taxa to the total biomass of macrozoobenthos at four study sites of Lake Krivoe 


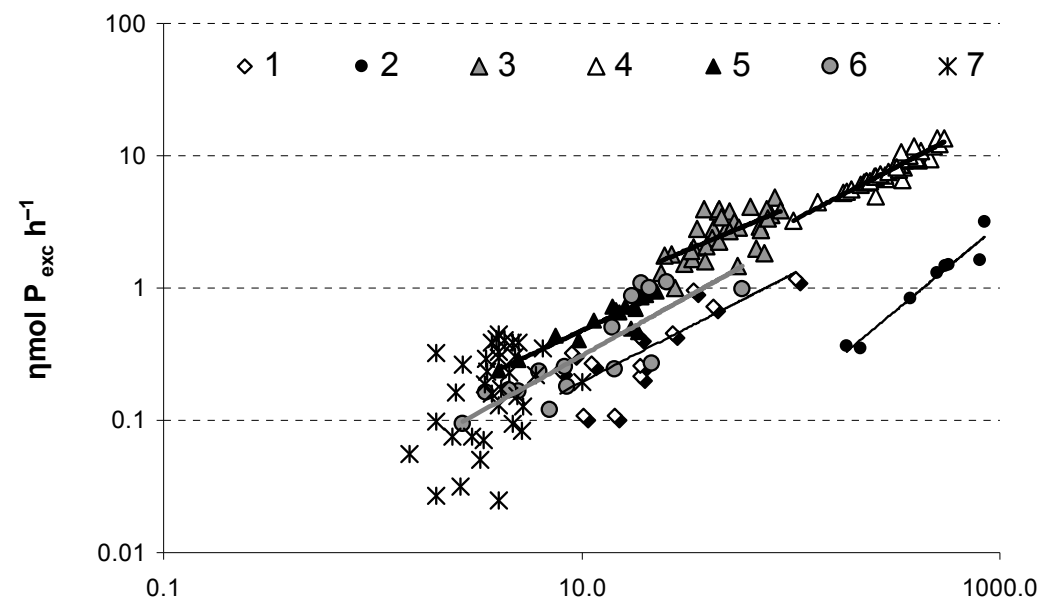

Wet weight, mg

Fig. 5. Phosphorus excretion rate $\left(\mathrm{P}_{-} \mathrm{PO}_{4} ; \mu \mathrm{mol} \mathrm{P} \mathrm{h}^{-1}\right)$ by diverse benthic animals versa their individual wet weight (WW, mg) at water temperature of $10{ }^{\circ} \mathrm{C}: 1$ - Sphaerium suecicum; 2 - Lymnaea stagnalis; 3 - Gammarus lacustris; 4 - Gammaracanthus loricatus; 5 - Monoporeia affinis; 6 - Lumbriculus variegates; 7 - Sergentia coracina

L. stagnalis and L. variegatus as well as between all amphipods. There are no any significant differences in regression lines of two pairs of species: L. stagnalis and $S$. suecicum $(\mathrm{F}=0.71$, $\mathrm{ns}, \mathrm{p}>0.05)$, and $M$. affinis and $L$. variegatus $(\mathrm{F}=0.43 ; \mathrm{ns}, \mathrm{p}>0.05)$. There were significant differences in dispersions between variables in S. suecicum and G. loricatus $(\mathrm{F}=6.38 ; \mathrm{p}<0.001)$. Also, slopes and intercepts of regression lines differed between $S$. suecicum versus $M$. affinis, G. lacustris, and L. variegatus $\left(\mathrm{t}_{\text {slopes }}=3.32-4.23\right.$; $\mathrm{p}<0.05)$, although their dispersions had no significant differences $(F=0.04-1.55 ; p>0.05)$.

The average dry body weight (DW) and mass specific excretion rates $\left(\mathrm{P}_{\text {exc }} / \mathrm{DW}\right)$ of animals differed between taxa (Table 4). Amphipods (M. affinis, G. lacustris) and chironomids tended to excrete SRP at significantly higher rates $\left(0.23-0.27 \eta \mathrm{mol} \mathrm{mg}^{-1} \mathrm{~h}^{-1}\right.$ at $\left.10{ }^{\circ} \mathrm{C}\right)$ than oligochaetes (0.17), and mollusks (0.01-0.04). The gastropod L. stagnalis tended to have the lowest SRP excretion rate as a result of highest body mass of the animals because of massive shell. Water temperature was found as the main determinant factor for SRP excretion activity in animals. Coefficient $\mathrm{Q}_{10}$ in the temperature range of $10-20^{\circ} \mathrm{C}$ varied slightly between species (Table 4).

The average values of $\mathrm{P}$ efflux caused by benthic excretion at study sites of the lake are presented on Fig. 6 (seasonal changes). The P efflux was significantly (F-test, $\mathrm{p}<0.01$ ) 5-6 times greater in littoral than in deep sites. It was lowest at St $1\left(0.3-1.62 \mu \mathrm{mol} \mathrm{m}^{-2} \mathrm{~d}^{-1}\right)$ and highest at St $4\left(2.2-14.4 \mu \mathrm{mol} \mathrm{m}{ }^{-2} \mathrm{~d}^{-1}\right)$. Differences in average $\mathrm{P}$ efflux between littoral sites as well as between deep sites were insignificant ( $p>0.05$; Table 3 ). At the same time, littoral benthos contributed $57-62 \%$ to the total P-efflux $\left(2.5 \mu \mathrm{mol} \mathrm{m} \mathrm{m}^{-2} \mathrm{~d}^{-1}\right)$, in spite of the littoral area (0-3 m) consists only $20 \%$ of the total lake area. The approximate values of the total P-flux on whole bottom area in Lake Krivoe ranged seasonally from 299 to 2332 averaging $1240 \mathrm{mmol} \mathrm{d}^{-1}$.

The littoral amphipod G. lacustris and the profundal amphipod $M$. affinis were 
Table 4. Min-Max and mean ( \pm SE) body weight (DW, mg), mass-specific excretion rates of soluble reactive

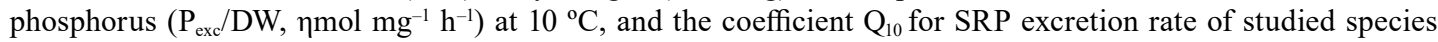
from Lake Krivoe

\begin{tabular}{|l|c|c|c|}
\hline \multicolumn{1}{|c|}{ Species } & $\mathrm{DW}$ & $\mathrm{P}_{\mathrm{exc}} / \mathrm{DW}$ & $\mathrm{Q}_{10}$ \\
\hline Lumbriculus variegatus & $0.7-11.7$ & $0.08-0.28$ & 2.1 \\
Sphaerium suecicum & $3.0 \pm 0.7$ & $0.17 \pm 0.02$ & \\
Lymnaea stagnalis & $1.8-169.0$ & $0.02-0.17$ & 2.0 \\
Monoporeia affinis & $68.5 \pm 17.9$ & $0.04 \pm 0.01$ & 3.0 \\
Gammarus lacustris & $36.0-169.0$ & $0.01-0.02$ & \\
Gammaracanthus loricatus & $101.1 \pm 17.2$ & $0.01 \pm 0.00$ & 2.6 \\
Sergentia coracina & $0.8-4.6$ & $0.10-0.30$ & \\
& $3.0 \pm 0.2$ & $0.23 \pm 0.01$ & 2.6 \\
\end{tabular}

St 1
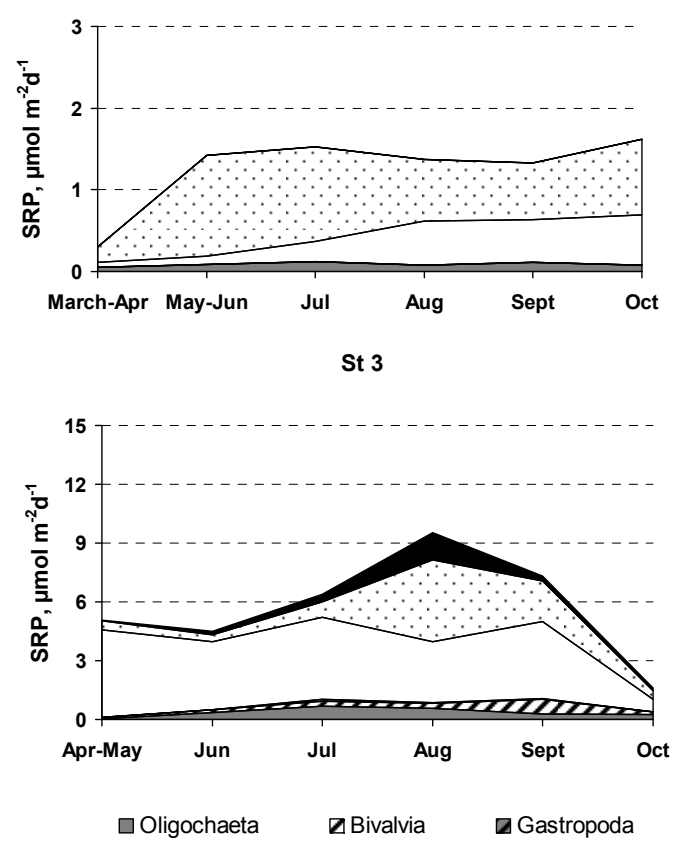

St 2

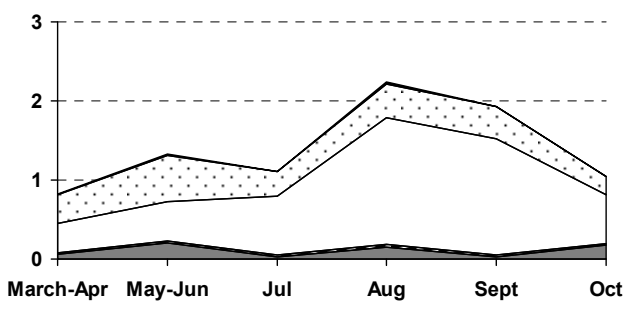

St 4

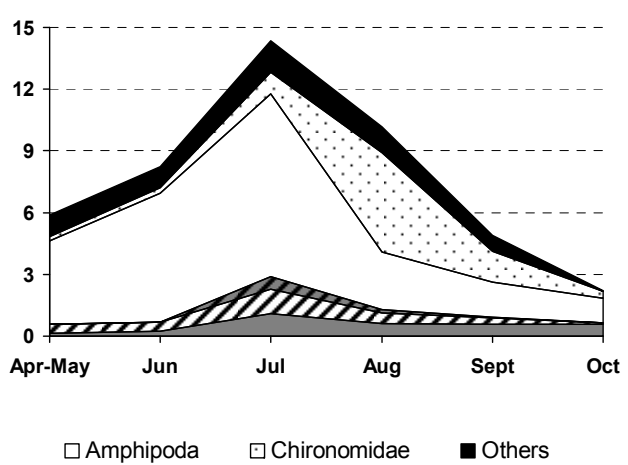

Fig. 6. SRP excretion fluxes $\left(\mu \mathrm{mol} \mathrm{m} \mathrm{m}^{-2} \mathrm{~d}^{-1}\right)$ of various macrobenthic taxa at four study sites of Lake Krivoe during season (mean for 2009-2013). Contribution of megabenthic Gammaracanthus loricatus to the SRP excretion flux is not included

the main contributors (up to $80 \%$ ) to the $\mathrm{P}$ deepest St 1 chironomids contributed up to efflux among macrobenthic invertebrates $70 \%\left(0.2-1.2 \mu \mathrm{mol} \mathrm{m} \mathrm{m}^{-1}\right)$ of the total flux at sites $2-4\left(1.6-8.9 \mu \mathrm{mol} \mathrm{m} \mathrm{m}^{-2} \mathrm{~d}^{-1}\right)$. At the but role of amphipods (M. affinis) declined 
$\left(0.1-0.6 \mu \mathrm{mol} \mathrm{m} \mathrm{m}^{-2} \mathrm{~d}^{-1}\right)$. At the same time, another megabenthic amphipod $G$. loricatus excreted 2.1-10.4 $\mu \mathrm{mol} \mathrm{m}^{-2} \mathrm{~d}^{-1}$ of SRP at St 1 .

\section{Activity}

of alkaline phosphatase

Relationships between the extracellular alkaline phosphatase activity (APA) and number and wet mass of amphipods in treatments are shown in Fig. 7. The activity of APA increased 3-8 times due to activity of amphipods (G. lacustris), comparing to the control. We found positive correlations between the activity of this enzyme and the abundance and the biomass of animals but correlation coefficient was high for APA versus abundance $(\mathrm{R}=0.83$; $\mathrm{n}=12, \mathrm{p}<0.05)$ and insignificant in the case of APA versus biomass $(\mathrm{R}=0.54 ; \mathrm{n}=12, \mathrm{p}>0.05)$. $\mathrm{P}$ excretion rate of the amphipod correlated positively with biomass of animals $(\mathrm{R}=0.78$; $\mathrm{n}=12, \mathrm{p}<0.05)$ and with APA $(\mathrm{R}=0.86 ; \mathrm{n}=12$, $\mathrm{p}<0.05)$.

\section{Discussion}

Positive relationships between $\mathrm{P}$ excretion rate and body mass of organisms are confirmed by this study as well as by other empirical data for different taxa: fish, zooplanktonic and benthic organisms (Johannes, 1964; Gutelmakher, 1981; Andersson el al., 1988; Schindler, Eby, 1997; Griffiths, 2006). We found differences in individual $\mathrm{P}$ excretion rates between taxa of high taxonomic ranks (class, order or family), such as Oligochaeta, Mollusca, and Chironomidae. Also, within order Amphipoda we found interspecies differences in $\mathrm{P}$ excretion rates between littoral $G$. lacustris and deepwater G. loricatus. Most likely, these differences related to differences in specific metabolic rates between these species. Conroy et al. (2005) also found differences in $\mathrm{P}$ excretion rates between species of the genus Dreissena.

Amphipods were main contributor of $\mathrm{P}$ efflux from the bottom to water in studied lake, where $70-90 \%$ of $\mathrm{P}$ released due to excretion of
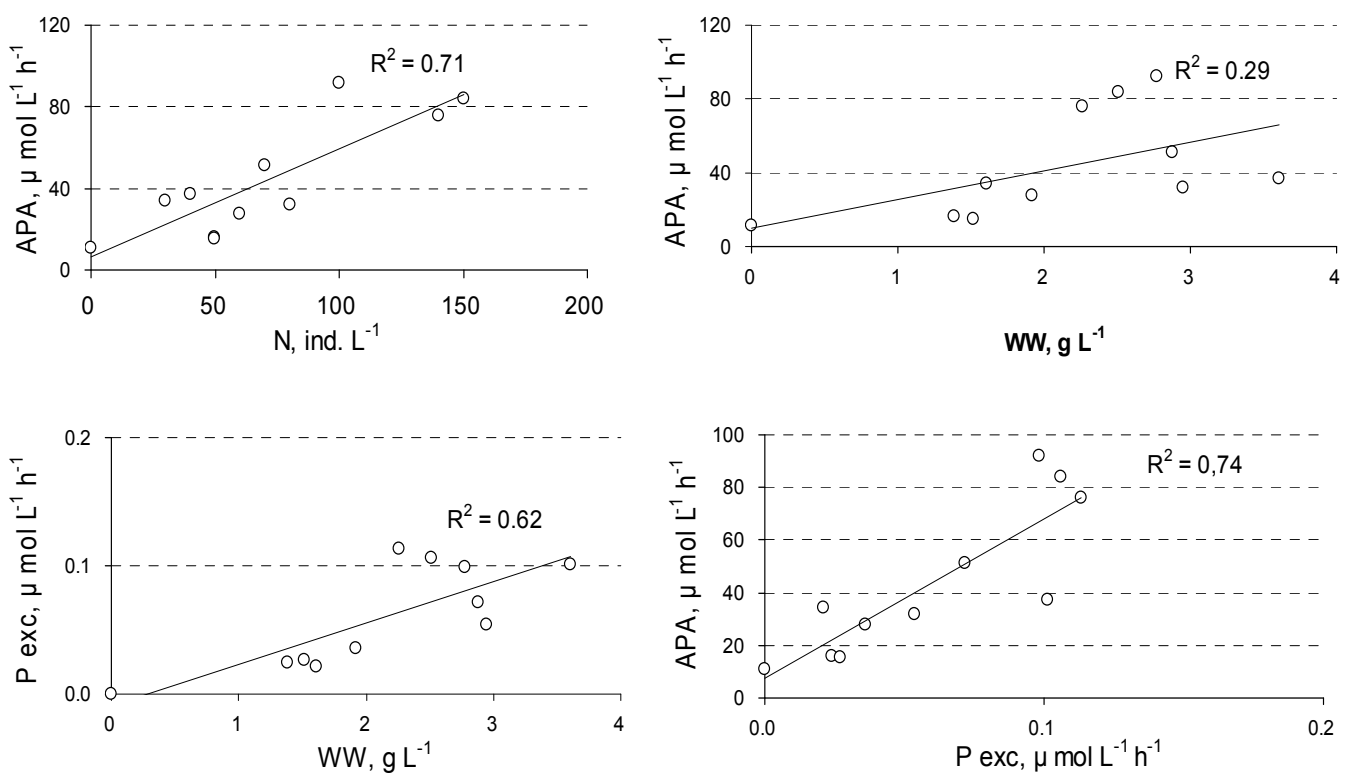

Fig. 7. Relationships between the extracellular alkaline phosphatase activity (APA) and abundance (N) and biomass (WW) of amphipods in treatments, and between soluble reactive phosphorus, excreted by amphipods $\left(\mathrm{P}_{\mathrm{exc}}\right)$ and their biomass and APA. $\mathrm{R}^{2}$ is coefficient of determination, $\mathrm{n}=12$ 
amphipods and rest on account of other taxa. In contrast, in eutrophic lakes (Acton, Donghu) P fluxes in oxic sites were determined, as a rule, by excretory activity of chironomids and tubificids (Devine, Vanni, 2002; Ji et al., 2011).

The variations in the $\mathrm{P}$ excretion rates are not only relate to characteristics of individual species/taxa but also reflect the character of environments. The obtained data confirmed that level of $P$ excretion rate in benthic animals depends on water temperature. These relationships cause the seasonal differences in $\mathrm{P}$ fluxes that were found also in other studies of zooplankton (Oude, Gulati, 1988) and zoobenthos (Devine and Vanni, 2002; Postolache et al., 2006).

The highest rate of the $\mathrm{P}$ efflux by excretion of benthic invertebrates was recorded in the littoral of studied lake and the lowest in the central sites. The greater P fluxes at littoral sites in comparison with central sites were also found in other lakes (Devine, Vanni, 2002; Ji et al. 2011, 2015). Difference in P flux between central and littoral sites in small lakes is obviously the result of spatial differences in physical and chemical traits, trophicity, and zoobenthic biomass.

Mobile benthic animals such as amphipods occurred to be able to influence the activity of extracellular alkaline phosphatase, raising its level in the water. These enzymes are produced by bacteria and algae and can catalyze the hydrolysis of soluble organic phosphorus, probable excreted by aquatic animals. It is widely known that activities and ratios of commonly measured enzymes can be used as indicators of microbial nutrient demand (Crowther et al., 2011).

Influence of invertebrates on the extracellular enzymes, which are responsible for the decomposition of organic matter and the cycling of nutrients, was found as notable in some other cases. Burrowing mangrove crabs could directly impact the nutrient cycling in mangrove sediment, thereby accordingly changing the microbial activity including enzymatic activity and microbial abundance (Luo, Gu, 2016). Extracellular enzyme activity is not only affected by environmental conditions but, also, reflects the available resources for algae and bacteria.

Animal excretory products could be not only in forms of DIP, but also dissolved organic $\mathrm{P}$ (DOP) and even particulate $\mathrm{P}$ fractions; and they may be highly bioavailable (Karl, Björkman, 2002; Stepanauskas et al., 2002; Nausch, Nausch, 2007). Plankton algae and bacteria producing their own phosphatases can facilitate liberation of bioavailable $\mathrm{P}$ from DOP compounds by phosphatase-catalysed hydrolysis (Wetzel, 2001; Chrost, Siuda, 2002). Phosphatase activity commonly occurred as high in environment, where ambient $\mathrm{P}$ is scarce (Healey, Hendzel, 1980; Pettersson, 1980; Gage, Gorham, 1985) as well as in the hyper-eutrophic ecosystem (urban Lake Donghu) at ample P concentrations (Zhou et al., 2007; Cao et al., 2005). Thus, the high activity of phosphatase in the water due to excretory activity of benthic organisms may testify about P acquisition (Sinsabaugh et al., 2012) and high bioavailability of excreted phosphates, facilitating of bacteria and algae growth and important for $\mathrm{P}$ cycle in water.

\section{Conclusion}

Despite the fact that phosphorus is the most studied of nutrients in the freshwater ecosystems, this study provides new evidences that benthic invertebrates can affect the internal phosphorus load and biomass of primary producers in the oligotrophic system. Mobile benthic invertebrates (amphipod crustaceans) were found as the most important contributor of phosphates excreted by benthic invertebrates due to their ability to move from bottom sediments to water and enrich the water column by this nutrient. The main flow of excreted phosphorus passes through the littoral zone of oligotrophic 
lake, elevating notably in warm period. Direct relationships, recorded between phosphorus excreted by animals and activity of extracellular phosphatase, indicate about high bioavailability of excreted compounds and important role of consumers in P-cycling but mechanisms of these interactions need further investigations and understanding.

We thank staff of the White Sea Biological Station “Kartesh" (ZIN RAS) for providing facilities and help during field and experimental works and Dr. E.S. Kravchuk (Institute of Biophysics SB RAS, Krasnoyarsk, Russia) for useful comments on this paper. This work presents results of the SinoRussian cooperation (grants from the National Natural Science Foundation of China 40911120038 and Russian Foundation for Basic Research 08-04-92217-GFEN_a) between Laboratory of Freshwater and Experimental hydrobiology (Russian Academy of Sciences, Zoological Institute, St. Petersburg, Russia) and Key Laboratory of Algal Biology (Chinese Academy of Sciences, Institute of Hydrobiology, Wuhan, China).

\section{References}

Andersson G., Granéli W., Stenson J. (1988) The influence of animals on phosphorus cycling in lake ecosystems. Hydrobiologia, 170: 267-284

Boon P.I. (1989) Organic matter degradation and nutrient regeneration in Australian freshwaters: I. Methods for exoenzyme assays in turbid aquatic environments. Archiv fur Hydrobiologie, 115: 339359

Cao X., Strojsová A., Znachor P., Zapomelová E. (2005) Detection of extracellular phosphatases in natural spring phytoplankton of a shallow eutrophic lake (Donghu, China). European Journal of Phycology, 40: 251-258

Chrost R.J., Siuda W. (2002) Ecology of microbial enzymes in lake ecosystems. Enzymes in the environment: activity ecology and applications. Burns R.G., Dick R.P. (eds.) New York, Marcel Dekker, p. 35-72

Conroy J.D., Edwards W.J., Pontius R.A., Kane D.D., Zhang H., Shea J.F., Richey J.N., Culver D.A. (2005) Soluble nitrogen and phosphorus excretion of exotic freshwater mussels (Dreissena spp.): potential impacts for nutrient remineralisation in western Lake Erie. Freshwater Biology, 50: $1146-1162$

Crowther T.W., Jones T.H., Boddy L., Baldrian P. (2011) Invertebrate grazing determines enzyme production by basidiomycete fungi. Soil Biology and Biochemistry, 43 (10): 2060-2068

Devine J.A., Vanni M.J. (2002) Spatial and seasonal variation in nutrient excretion by benthic invertebrates in a eutrophic reservoir. Freshwater Biology, 47: 1107-1121

Gage M.A., Gorham E. (1985) Alkaline phosphatases activity and cellular phosphorus as an index of the phosphorus status of phytoplankton in Minnesota lakes. Freshwater Biology, 15: 227-233

Gardner W.S., Nalepa T.F., Quigley M.A., Malczyk J.M. (1981) Release of phosphorus by certain benthic invertebrates. Canadian Journal of Fisheries and Aquatic Sciences, 38: 978-981

Golterman H.L., Clymo R.S., Ohnstad M.A.M. (1978) Method for chemical analysis of fresh water. IBP Handbook, 8. Oxford, Blackwell, 213 p.

Golubkov S.M., Berezina N.A. (2012) Phosphorus excretion by bottom invertebrates of inland water bodies. Doklady Biology Sciences, 444: 192-194

$$
-499-
$$


Griffiths D. (2006) The direct contribution of fish to lake phosphorus cycles. Ecology of Freshwater Fish, 15 (1): 86-95

Gutelmakher B.L. (1981) Quantitative estimation of phosphorus cycling via primary links of trophic webs. Oceanologia, 25 (4): 634-638

Healey F.P., Hendzel L.L. (1980) Physiological indicators of nutrient deficiency in lake phytoplankton. Canadian Journal of Fisheries and Aquatic Sciences, 37: 442-453

Hecky R.E., Kilham P. (1988) Nutrient limitation of phytoplankton in freshwater and marine environments: A review of recent evidence on the effects of enrichment. Limnology and Oceanography, 33: $796-822$

Ingall E.D., Bustin R.M., Van Capellen P. (1993) Influence of water column anoxia on the burial and preservation of carbon and phosphorus in marine shales. Geochimica et Cosmochimica Acta, 57: 303-316

Ji L., Berezina N.A., Golubkov S.M., Cao X., Golubkov M.S., Song C., Umnova L.P., Zhou Y. (2011) Phosphorus flux by bottom macroinvertebrates in a shallow eutrophic Lake Donghu. Knowledge and Management of Aquatic Ecosystems, 402 (11). DOI: 10.1051/kmae $/ 2011073$

JiL., Song C., Cao X., Deng D. (2015) Spatial variation in nutrient excretion by macrozoobenthos in a Chinese large shallow lake (Lake Taihu). Journal of Freshwater Ecology, 30 (1): $169-180$

Johannes R.E. (1964) Phosphorus excretion and body size in marine animals: microzooplankton and nutrient regeneration. Science, 146 (3646): 923-924

Karl D.M., Björkman K.M. (2002) Dynamics of DOP. Miogeochemistry of marine dissolved organic matter. Hansell D., Carlson C.A. (eds.) Amsterdam, Elsevier, p. 249-366

Luo L., Gu J-D. (2016) Influence of macrofaunal burrows on extracellular enzyme activity and microbial abundance in subtropical mangrove sediments. Microbial Ecology. DOI: 10.1007/s00248016-0844-3

Murphy J., Riley J.P. (1962) A modified single solution for the determination of phosphate in natural waters. Analytica Chimica Acta, 27: 31-36

Nausch M., Nausch G. (2007) Bioavailable dissolved organic phosphorus and phosphorus use by heterotrophic bacteria. Aquatic Biology, 1: 151-160

Oude P.J., Gulati R.D. (1988) Phosphorus and nitrogen excretion rates of zooplankton from the eutrophic Loosdrecht lakes, with notes on other $\mathrm{P}$ sources for phytoplankton requirements. Hydrobiologia, 169 (3): 379-390

Pettersson K. (1980) Alkaline phosphatase activity and algal surplus phosphorus as phosphorusdeficiency indicators in Lake Erken. Archiv für Hydrobiologie, 89: 54-87

Postolache C., Risnoveanu G., Vadineanu A. (2006) Nitrogen and phosphorous excretion rates by tubificids from the Prahova River (Romania). Hydrobiologia, 553: 121-127

Ricker W.E. (1975) Computation and interpretation of biological statistics of fish populations. Bulletin of the Fisheries Research Board of Canada, 191. Ottawa, Department of the environment fisheries and marine service, $382 \mathrm{p}$.

Schindler D.E., Eby L.A. (1997) Stoichiometry of fishes and their prey: implications for nutrient recycling. Ecology, 78: 1816-1832

Schindler D.W. (1977) Evolution of phosphorus limitation in lakes. Science, 195: 260-262

$$
-500-
$$


Sinsabaugh R.L., Shah J.J.F., Hill B.H., Elonen C.M. (2012) Ecoenzymatic stoichiometry of stream sediment with comparison to terrestrial soils. Biogeochemistry, 111 (1-3): 455-467

Stepanauskas R., Jørgensen N.O.G., Eigaard O.R., Žvikas A., Tranvik L.J., Leonardson L. (2002) Summer inputs of riverine nutrients to the Baltic Sea: bioavailability and eutrophication relevance. Ecological Monographs, 72: 579-597

Tarvainen M., Ventela A.-M., Helminen H., Sarvala J. (2005) Nutrient release and resuspension generated by ruffe and chironomids. Freshwater Biology, 50: 447-458

Torress L.E., Vanni M.J. (2006) Stoichiometry of nutrient excretion by fish: interspecific variation in hypereutrophic lake. Oikos, 116: 259-270

Vanni M.J. (2002) Nutrient cycling by animals in freshwater ecosystems. Annual Review of Ecology and Systematics, 33: 341-370

Vanni M.J., Renwick W.H., Headworth J.L., Auch J.D., Schaus M.H. (2001) Dissolved and particulate nutrient flux from three adjacent agricultural watersheds: a five-year study. Biogeochemistry, 54: $85-114$

Vinarsky M.V., Kantor Y.I. (2016) Analytical catalogue of fresh and brackish water molluscs of Russia and adjacent countries. Moscow, KMK Scientific Press, 544 p.

Vrba J., Machacek J. (1994) Release of dissolved extracellular b-N-acetylglucosaminidase during crustacean molting. Limnology and Oceanography, 39: 712-716

Westheimer F.H. (1987) Why nature chose phosphates. Science, 235: 1173-1178

Wetzel R.G. (2001) Limnology: lake and river ecosystems. London, Academic Press, 1006 p.

Wilhelm F.M., Hudson J.J., Schindler D.W. (1999) Contribution of Gammarus lacustris to phosphorus recycling in a fishless alpine lake. Canadian Journal of Fisheries and Aquatic Sciences, 56 (9): 1679-1686

Winberg G.G. (ed.) (1975) Biological productivity of northern lakes. 1. Lakes Krivoe and Krugloe. Proceedings of ZIN AS USSR 56. Leningrad, Nauka, 228 p. (in Russian)

Zhou Y., Cao X., Song C., Li J., Chen G., Peng L. (2007) Variations in kinetics of alkaline phosphatase in sediments of eutrophic, shallow, Chinese lakes. Hydrobiologia, 581: 109-116 